\title{
Pseudomonas ficuserectae sp. nov., the Causal Agent of Bacterial Leaf Spot of Ficus erecta Thunb.
}

\author{
MASAO GOTO \\ Faculty of Agriculture, Shizuoka University, 836 Ohya, Shizuoka 422, Japan
}

\begin{abstract}
Pseudomonas ficuserectae, a new nonfluorescent, phytopathogenic pseudomonad species, is described. This bacterium produces dark brown, water-soaked spots on the leaves and stems of Ficus erecta Thunb., resulting either in defoliation or shoot blight on severely infected plants. The colonies on nutrient agar plates are white, circular, and 3 to $4 \mathrm{~mm}$ in diameter after 6 days. $P$. ficuserectae is similar to Pseudomonas amygdali in many properties. The differences between these two species include size of colonies on agar plates, hydrolysis of Tween 80 , production of $\mathrm{H}_{2} \mathrm{~S}$, utilization of ribose, raffinose, mannitol, sorbitol, and malonate, and pathogenicity. The deoxyribonucleic acid base composition of the type strain of $P$. ficuserectae, strain L7, is $59 \mathrm{~mol} \%$ guanine plus cytosine. The specific epithet of this new species reflects the pathogenicity of the bacterium on $F$. erecta Thunb.
\end{abstract}

Since 1973, a bacterial disease has been observed in Japan on the tree Ficus erecta Thunb. (Japanese common name, Inubiwa), which is often planted in gardens as an ornamental plant. This disease is characterized by small, watersoaked spots on the leaves and shoot blight, and a nonfluorescent pseudomonad has been consistently isolated from diseased tissues. Therefore, I performed a taxonomic study comparing this organism with three nonfluorescent pseudomonads, Pseudomonas andropogonis (Smith) Stapp 1928 (14), Pseudomonas amygdali Psallidas and Panagopoulos 1975 (8), and Pseudomonas pseudoalcaligenes subsp. citrulli Schaad et al. $1978(10)$, which are similar in some respects to the bacterium isolated from diseased $F$. erecta tissues. Pseudomonas syringae pv. phaseolicola (Burkholder) Young et al. 1978 (16) was also included as a reference bacterium.

\section{MATERIALS AND METHODS}

Bacteria. The bacterial strains used in this study are listed in Table 1. Eleven cultures of the Ficus bacterium were isolated from new lesions formed on young leaves and twigs by the conventional plating method on yeast extract-peptone agar $(0.5 \%$ yeast extract, $1.0 \%$ peptone, $1.5 \%$ agar, $\mathrm{pH} 6.8$ ). Small white colonies grew on the plates in 2 days at $28^{\circ} \mathrm{C}$. Single colonies were selected and grown on yeast extractpeptone agar slants. The cultures were maintained at $4^{\circ} \mathrm{C}$ for routine work.

Pathogenicity. Inoculation tests were made on $F$. erecta Thunb., Ficus carica L. (cultivar unknown), Morus alba L. (cultivar unknown), and Prunus armeniaca L. cv. Wasesuimitsu; 2-year-old plants grown from cuttings were inoculated either by spraying with bacterial suspensions (concentration, $10^{8}$ cells per $\mathrm{ml}$ ) over young shoots or by puncturing mature leaves and stems with a needle through drops of bacterial suspension placed on the plant surface. The inoculated plants were kept in a mist chamber for $24 \mathrm{~h}$ and then transferred to a greenhouse, where disease development was monitored.

Bacteriological properties. Cell size was measured under a light microscope after staining with Ziehl carbolfuchsin (12). Poly- $\beta$-hydroxy-butyrate accumulation was detected either by staining with sudan black (9) or by observing under a phase-contrast microscope a wet mount of cells grown on a synthetic medium $\left(0.05 \% \quad \mathrm{NH}_{4} \mathrm{H}_{2} \mathrm{PO}_{4}, 0.02 \% \quad \mathrm{MgSO}_{4} \cdot 7 \mathrm{H}_{2} \mathrm{O}\right.$, $0.02 \% \mathrm{KCl}, 5 \%$ glucose, $\mathrm{pH} 6.8$ ) for 3 to 5 days. The modified Yamanaka method was used for flagellar staining (11). Reactions for catalase, amino acid decarboxylase, amylase, urease, and Kovacs oxidase, reduction of $\mathrm{KNO}_{3}$, and production of acetoin, 2-ketogluconate, and indole were tested by method 1 , and production of $\mathrm{H}_{2} \mathrm{~S}$ was tested by method 3 described in Cowan and Steel's Manual for the Identification of Medical Bacteria, 2nd ed. (2). Phenylalanine deaminase was tested on 2-day-old phenylalanine agar slant cultures by method 2 of the same manual. Methods described in this manual were also used to determine the results for the litmus milk reaction, gelatin liquefaction, the methyl red test, growth inhibition by $\mathrm{KCN}$, the Hugh-Leifson test, and esculin hydrolysis. The methods of Dye were used to test utilization of asparagine as a sole source of carbon and nitrogen and tolerance to $\mathrm{NaCl}$ (4). The production of reducing substances from sucrose, arginine dihydrolase, and levan formation were tested by methods described in the Laboratory Guide for Identification of Plant Pathogenic Bacteria (9). Utilization of carbon sources was tested by using the basal media developed by Ayers et al. (1) and by Starr (15). Denitrification was tested by the method of Stanier et al. (13). Pigmentation was tested on King B medium (5).

G $+\mathbf{C}$ content of DNA. Deoxyribonucleic acid (DNA) was isolated and purified by the method of Marmur 
TABLE 1. Pseudomonas strains included in this study

\begin{tabular}{|c|c|c|c|}
\hline Taxon & Strain(s) & History $^{a}$ & Habitat \\
\hline Pseudomonas ficuserectae & $\begin{array}{l}\mathrm{L} 2, \mathrm{~L} 3, \mathrm{~L} 5, \mathrm{~L} 6, \mathrm{~L} 7, \mathrm{~L} 8, \mathrm{~L} 9 \\
\quad \mathrm{~L} 10, \mathrm{~L} 11, \mathrm{~S} 1, \mathrm{~S} 2^{b}\end{array}$ & Goto & F. erecta \\
\hline $\begin{array}{l}\text { Pseudomonas pseudoalcaligenes } \\
\text { subsp. citrulli }\end{array}$ & PDDCC 6521, PDDCC 6522 & $\begin{array}{l}\text { Schaad } \\
\text { (PDDCC) }\end{array}$ & Watermelon \\
\hline Pseudomonas amygdali & PDDCC $3918^{\mathrm{T}}$, PDDCC 3920 & $\begin{array}{l}\text { Panagopoulos } \\
\text { (PDDCC) }\end{array}$ & Almond \\
\hline Pseudomonas andropogonis & PA1 ${ }^{c}$ & Goto & Sorghum \\
\hline Pseudomonas andropogonis & PA21 ${ }^{\circ}$ & Goto & Clover \\
\hline Pseudomonas andropogonis & PA31' & Goto & Strelitzia \\
\hline $\begin{array}{l}\text { Pseudomonas syringae pv. } \\
\text { phaseolicola }\end{array}$ & $P P 1^{c}$ & Goto & $\begin{array}{r}\text { Kidney } \\
\text { bean }\end{array}$ \\
\hline
\end{tabular}

${ }^{a}$ Person who isolated the strain(s). PDDCC, Plant Diseases Division Culture Collection, Auckland, New Zealand.

${ }^{b}$ Strains L2, L3, L5, L6, L7, L8, L9, L10, and L11 were isolated from leaves, and strains S1 and S2 were isolated from stems.

${ }^{c}$ Culture Collection of Phytopathogenic Bacteria, at the Laboratory of Plant Pathology, Shizuoka University, Shizuoka, Japan.

(6). The guanine-plus-cytosine $(\mathrm{G}+\mathrm{C})$ content of the DNA was calculated by using the equation of Marmur and Doty (7) and the thermal denaturation temperature, which was measured with a Gilford model 250 spectrophotometer. DNA of Micrococcus luteus (Schroeter) Cohn strain IAM 1056 was used as a reference; the base composition of this DNA was 72 $\mathrm{mol} \% \mathrm{G}+\mathrm{C}$.

\section{RESULTS AND DISCUSSION}

The 11 strains of the Ficus bacterium were identical in their morphological, physiological, and biochemical properties. In addition, as shown below, they were distinct from strains of three other phytopathogenic nonfluorescent species (Pseudomonas amygdali, Pseudomonas pseudoalcaligenes subsp. citrulli, Pseudomonas andropogonis) and Pseudomonas syringae pv. phaseolicola. The name Pseudomonas ficuser- ectae sp. nov. is proposed for the new strains.

Pseudomonas ficuserectae sp. nov. Pseudomonas ficuserectae (fi.cus.e.rećtae. Ficus erecta name of host species; L. n. ficuserectae of Ficus erecta) cells are gram-negative, non-encapsulated, nonsporeforming rods with an average size of 2.0 by $0.5 \mu \mathrm{m}$ and are motile by means of one to five polar flagella (Fig. 1). Poly- $\beta$-hydroxybutyrate granules accumulate. Colonies on yeast extract-peptone agar plates at $28^{\circ} \mathrm{C}$ are white, transparent, circular, convex, and 0.1 to $0.3 \mathrm{~mm}$ in diameter after 2 days and 2 to $3 \mathrm{~mm}$ in diameter after 6 days. Growth on yeast extractpeptone agar slants becomes very viscid after several days.

Pseudomonas ficuserectae was identical to the other four species studied in being positive for the following tests: motility, aerobic growth, catalase reaction, oxidative metabolism of fruc-

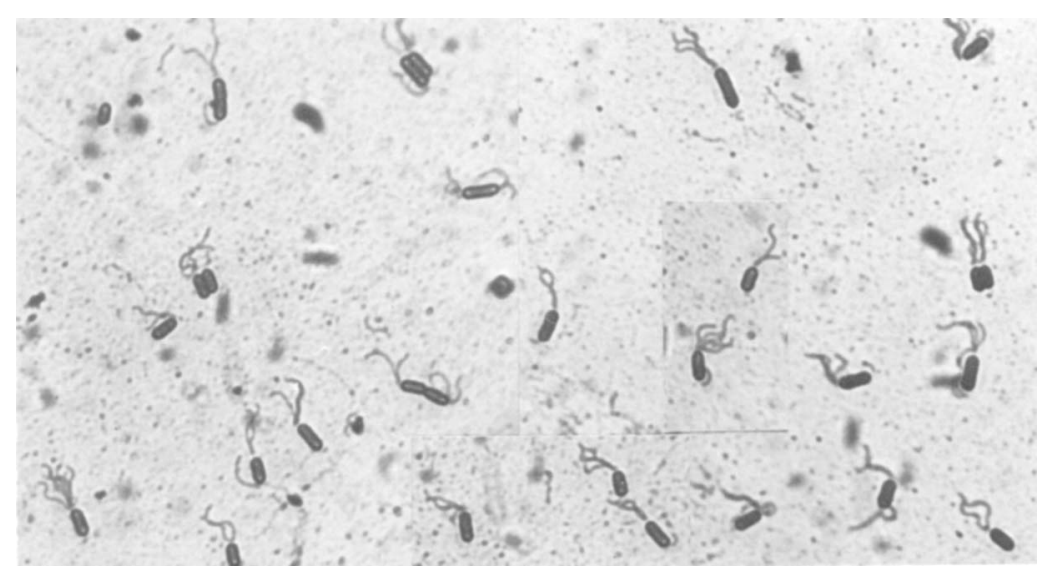

FIG. 1. Pseudomonas ficuserectae cells. 
TABLE 2. Phenotypic characteristics of Pseudomonas ficuserectae, Pseudomonas amygdali, Pseudomonas pseudoalcaligenes subsp. citrulli, Pseudomonas andropogonis, and Pseudomonas syringae pv. phaseolicola

\begin{tabular}{|c|c|c|c|c|c|}
\hline Character & $\begin{array}{c}\text { Pseudo- } \\
\text { monas } \\
\text { ficuserectae }\end{array}$ & $\begin{array}{l}\text { Pseudo- } \\
\text { monas } \\
\text { amygdali }\end{array}$ & $\begin{array}{c}\text { Pseudomonas } \\
\text { pseudoalcaligenes } \\
\text { subsp. citrulli }\end{array}$ & $\begin{array}{l}\text { Pseudomonas } \\
\text { andropogonis }\end{array}$ & $\begin{array}{c}\text { Pseudomonas } \\
\text { syringae pv. } \\
\text { phaseolicola }\end{array}$ \\
\hline Flagella & $1-5$ (polar) & $1-6$ (polar) & 1 (polar) & $1-3$ (polar) & 1-3 (polar) \\
\hline $\begin{array}{l}\text { Poly- } \beta \text {-hydroxybutyrate } \\
\text { accumulation }\end{array}$ & + & + & - & + & - \\
\hline Oxidase & - & - & + & - & - \\
\hline Growth at $41^{\circ} \mathrm{C}$ & - & - & + & - & - \\
\hline Growth at $4^{\circ} \mathrm{C}$ & + & + & - & + & + \\
\hline $\begin{array}{l}\text { Utilization of asparagine as } \mathrm{C} \text { and } \\
\mathrm{N} \text { sources }\end{array}$ & + & + & - & + & + \\
\hline Nitrate reduction & - & - & + & - & - \\
\hline Levan formation & + & + & - & - & + \\
\hline Gelatin liquefaction & - & - & \pm & - & - \\
\hline Tween 80 hydrolysis & - & + & + & - & + \\
\hline $\mathrm{H}_{2} \mathrm{~S}$ production & - & + & + & - & - \\
\hline Oxidation of gluconate & - & - & + & - & - \\
\hline Reducing substances from sucrose & + & + & + & - & + \\
\hline Urease & - & - & + & + & - \\
\hline Arginine decarboxylase & - & - & $+(\mathrm{d})$ & - & - \\
\hline Growth in $4 \% \mathrm{NaCl}$ & - & - & + & + & - \\
\hline $\mathrm{G}+\mathrm{C}$ content & $59 \mathrm{~mol} \%$ & $61 \mathrm{~mol} \%$ & $66 \mathrm{~mol} \%{ }^{b}$ & $\mathrm{ND}^{c}$ & ND \\
\hline \multicolumn{6}{|l|}{ Utilization of: } \\
\hline L-Arabinose & + & + & - & + & + \\
\hline D-Arabinose & - & - & - & - & - \\
\hline Xylose & - & - & - & + & + \\
\hline Ribose & - & + & + & + & + \\
\hline Glucose & + & + & - & + & + \\
\hline Mannose & + & + & - & + & + \\
\hline Rhamnose & - & - & - & + & $+(\mathrm{d})$ \\
\hline Cellobiose & - & - & - & - & $+(\mathrm{d})$ \\
\hline Lactose & - & - & - & + & - \\
\hline Saccharose & + & + & - & - & + \\
\hline Melibiose & - & - & - & + & + \\
\hline Raffinose & + & - & - & - & + \\
\hline Melezitose & - & - & - & + & - \\
\hline Ethanol & - & - & + & - & - \\
\hline Glycerol & + & - & + & + & + \\
\hline Inositol & - & - & - & + & - \\
\hline Mannitol & - & + & - & + & + \\
\hline Adonitol & - & - & - & + & - \\
\hline Sorbitol & $-d$ & + & - & + & - \\
\hline Formate & - & - & - & - & + \\
\hline Acetate & - & - & + & + & - \\
\hline Lactate & - & - & + & + & - \\
\hline Maleate & - & - & + & - & + \\
\hline Malonate & + & $+(\mathrm{d})$ & + & + & + \\
\hline Propionate & - & - & + & - & - \\
\hline Caprate & - & - & + & - & - \\
\hline Tartrate & - & - & + & - & - \\
\hline$\beta$-Alanine & - & - & + & - & - \\
\hline Serine & - & - & + & + & + \\
\hline Leucine & - & - & + & - & - \\
\hline$\gamma$-Aminobutyric acid & - & - & + & + & + \\
\hline Valine & - & - & + & - & - \\
\hline Ethylene glycol & - & - & + & - & - \\
\hline
\end{tabular}

${ }^{a}+$, Positive reaction; - , negative reaction; \pm , weak reaction; (d), delayed reaction.

${ }^{b}$ From reference 10 .

c ND, Not determined.

${ }^{a}$ Strain $\mathrm{S} 2$ was positive. 
TABLE 3. Main differences between Pseudomonas ficuserectae and Pseudomonas amygdali

\begin{tabular}{|c|c|c|c|c|c|c|c|c|c|}
\hline \multirow[b]{2}{*}{ Species } & \multirow{2}{*}{$\begin{array}{c}\text { Size of colonies } \\
\text { on nutrient agar } \\
\text { plates after } 7 \\
\text { days }(\mathrm{mm})\end{array}$} & \multirow{2}{*}{$\begin{array}{l}\text { Hydrol- } \\
\text { ysis of } \\
\text { Tween } \\
80\end{array}$} & \multirow{2}{*}{$\begin{array}{c}\text { Produc- } \\
\text { tion of } \\
\mathrm{H}_{2} \mathrm{~S}\end{array}$} & \multicolumn{5}{|c|}{ Utilization of: } & \multirow{2}{*}{$\begin{array}{c}\mathrm{G}+\mathrm{C} \\
\text { content } \\
(\mathrm{mol} \%)\end{array}$} \\
\hline & & & & Ribose & $\begin{array}{l}\text { Raffi- } \\
\text { nose }\end{array}$ & $\begin{array}{l}\text { Glyc- } \\
\text { erol }\end{array}$ & $\begin{array}{c}\text { Manni- } \\
\text { tol }\end{array}$ & $\begin{array}{c}\text { Sorbi- } \\
\text { tol }\end{array}$ & \\
\hline Pseudomonas ficuserectae & $3-4$ & - & - & - & + & + & - & $-a$ & 59 \\
\hline Pseudomonas amygdali & $0.3-1.0$ & + & + & + & - & - & + & + & 61 \\
\hline
\end{tabular}

${ }^{a}$ Strain S2 was positive.

tose, alkaline reaction of litmus milk, growth in $3 \% \mathrm{NaCl}$, utilization of $\mathrm{L}$-galactose, fructose, malate, fumarate, succinate, and citrate, and tobacco hypersensitive reaction. Negative reactions were obtained in the following tests: Gram stain, growth factor requirement, denitrification, utilization of arginine and betaine as carbon sources, arginine dihydrolase, starch hydrolysis, decarboxylase reaction with lysine and ornithine, phenylalanine deaminase, growth in 5\% $\mathrm{NaCl}$ and $0.0075 \% \mathrm{KCN}$, indole production, methyl red test, acetoin production, potato rot, and utilization of D-galactose, maltose, trehalose, erythritol, dulcitol, xylan, inulin, glycogen, starch, carboxymethyl cellulose, salicin, $\alpha$-methyl-D-glucoside, esculin, oxalate, glycolate, butyrate, sebacate, hippurate, arginine, betaine, valine, and ethylene glycol.

Additional characteristics of Pseudomonas ficuserectae that differentiate this species from Pseudomonas amygdali, Pseudomonas pseudoalcaligenes subsp. citrulli, Pseudomonas andropogonis, and Pseudomonas syringae pv. phaseolicola are shown in Table 2. Pseudomonas ficuserectae is clearly distinguished from Pseudomonas andropogonis and Pseudomonas syringae pv. phaseolicola by its limited ability to utilize sugars and sugar alcohols and from $P$ seudomonas pseudoalcaligenes subsp. citrulli in the limited number of organic acids utilized, as well as by its negative reactions in some physiological and biochemical tests. In contrast, Pseudomonas ficuserectae is similar to Pseudomonas amygdali in phenotypic characteristics (8). The differences between these two species are shown in Table 3. In addition to differences in seven biochemical properties and $\mathrm{G}+\mathrm{C}$ content, the strains of Pseudomonas amygdali are quite distinctive in that their growth on yeast extract-peptone agar plates is retarded; colonies are only 0.3 to $1.0 \mathrm{~mm}$ in diameter after 7 days at $28^{\circ} \mathrm{C}$ in contrast to $P$. ficuserectae colonies, which are 3 to $4 \mathrm{~mm}$ in diameter. The delayed growth of Pseudomonas amygdali on agar plates is consistent even after repeated subculturing on the same medium.

The disease produced by Pseudomonas ficuserectae is characterized by leaf spots which develop beside the thick veins (Fig. 2A). These spots are angular, 1 to $3 \mathrm{~mm}$ across, and dark green to dark brown, with a water-soaked appearance. The individual spots enlarge gradually and coalesce to form large lesions which invariably are surrounded by a yellow halo. Severely infected leaves often defoliate. In early spring,

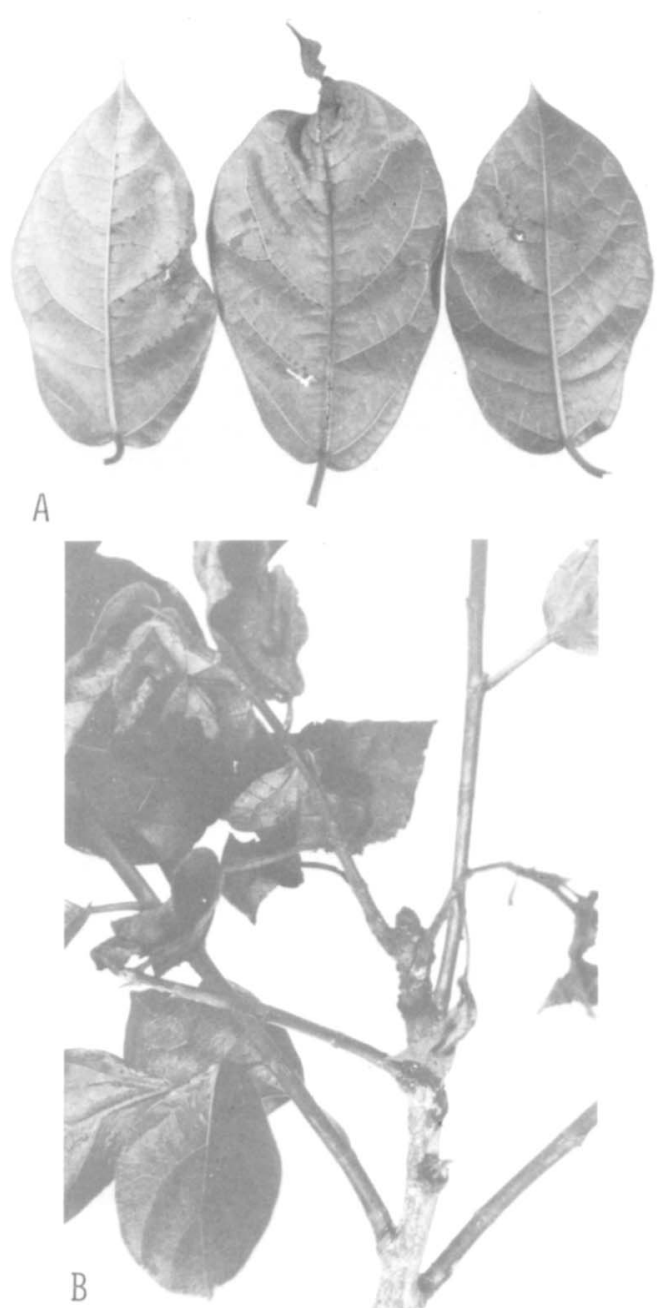

FIG. 2. Plant infected with Pseudomonas ficuserectae. (A) Leaves showing spots which develop beside the veins. (B) Shoot blight. 
the disease also develops on new shoots, causing shoot blight which results in dieback of the twigs (Fig. 2B).

In inoculation tests, Pseudomonas ficuserectae produced small, water-soaked dark green spots on the leaves of $F$. erecta 4 to 5 days after inoculation by the spraying method. These spots enlarged slowly to form angular lesions with or without halos, were 1 to $2 \mathrm{~mm}$ across after 10 days, and turned dark brown. The strains of Pseudomonas amygdali, Pseudomonas pseudoalcaligenes subsp. citrulli, Pseudomonas andropogonis, and Pseudomonas syringae pv. phaseolicola tested did not produce any symptoms on F. erecta. None of the bacteria studied, including Pseudomonas ficuserectae, was pathogenic on $F$. carica L., M. alba L., or Prunus armeniaca $\mathrm{L}$. when either the pricking method or the spraying method of inoculation was used.

The base composition of Pseudomonas ficuserectae DNA is $59 \mathrm{~mol} \%$ guanine plus cytosine.

The type strain is strain L7 (= ATCC $35104=$ PDDCC 7848).

In 1980, Pseudomonas syringae pv. fici was reported from India as the pathogenic agent of bacterial leaf spot of Ficus palmata Forsk. (3). This bacterium shares with Pseudomonas ficuserectae many biochemical properties; however, these two organisms do differ in utilization of carbohydrates. The type strain of Pseudomonas syringae pv. fici has not been designated, and no culture has been available from any culture collection; thus, a direct comparison between Pseudomonas ficuserectae and Pseudomonas syringae $\mathrm{pv}$. fici could not be undertaken.

\section{ACKNOWLEDGMENTS}

I thank K. Yamasato, Institute of Applied Microbiology, University of Tokyo, Tokyo, Japan, for determining the DNA base composition.

\section{LITERATURE CITED}

1. Ayers, S. H., P. Rupp, and W. T. Johnson. 1919. A study of the alkali-forming bacteria in milk. U.S. Department of Agriculture Bulletin 782. U.S. Department of Agriculture, Washington, D.C.

2. Cowan, S. T. 1974. Cowan and Steel's manual for the identification of medical bacteria, 2nd ed. Cambridge University Press, Cambridge.

3. Durgapal, J. C., and B. Singh. 1980. Taxonomy of pseudomonads pathogenic to horse-chestnut, wild fig and wild cherry in India. Indian Phytopathol. 33:533-535.

4. Dye, D. W. 1963. A taxonomic study of the genus Erwinia. I. The "amylovora group." N. Z. J. Sci. 11:590-607.

5. King, E. O., M. K. Ward, and D. E. Raney. 1954. Two simple media for the demonstration of pyocyanin and fluorescein. J. Lab. Med. 44:301-307.

6. Marmur, J. 1961. A procedure for the isolation of deoxyribonucleic acid from microorganisms. J. Mol. Biol. 3:208218.

7. Marmur, J., and P. Doty. 1962. Determination of the base composition of deoxyribonucleic acid from its thermal denaturation temperature. J. Mol. Biol. 5:109-118.

8. Psallidas, P. G., and C. G. Panagopoulos. 1975. A new bacteriosis of almond caused by Pseudomonas amygdali sp. nov. Ann. Inst. Phytopathol. Benaki 11:94-108.

9. Schaad, N. W. (ed.). 1980. Laboratory guide for identification of plant pathogenic bacteria. American Phytopathological Society, Minneapolis, Minn.

10. Schaad, N. W., G. Sowell, Jr., R. W. Goth, R. R. Colwell, and R. E. Webb. 1978. Pseudomonas pseudoalcaligenes subsp. citrulli subsp. nov. Int. J. Syst. Bacteriol. 28:117125.

11. Shirata, A., and M. Goto. 1981. Bacterial flagella staining by modified Yamanaka method. Shokubutsu Bōek 35:325-326. (In Japanese.)

12. Society of American Bacteriologists. 1957. Manual of microbiological methods. McGraw-Hill Book Co., Inc., New York.

13. Stanier, R. Y., N. J. Palleroni, and M. Doudoroff. 1966. The aerobic pseudomonads: a taxonomic study. J. Gen. Microbiol. 43:159-271.

14. Stapp, C. 1928. Schizomycetes (Spaltpilze oder Bacterien) p. 1-295. In Sorauer, Handbuch der Pflanzenkrankheiten, 5th ed., vol. 2. Paul Parey, Berlin.

15. Starr, M. P. 1946. The nutrition of phytopathogenic bacteria. I. Minimal. nutritive requirements of the genus Xanthomonas. J. Bacteriol. 51:131-143.

16. Young, J. M., D. W. Dye, and J. P. Wilkie. 1978. Genus VII. Pseudomonas Migula 1894. N. Z. J. Agric. Res. 21:158-161. 